\title{
Ecophysiological adaptation and metal accumulation in water hyacinth from two tropical rivers
}

\author{
Angela P. Vitória ${ }^{1 *}$, Frederico Lage-Pinto ${ }^{1}$, Leonardo B. Campaneli ${ }^{1}$, Marcelo G. Almeida ${ }^{1}$, \\ Cristina M. M. Souza ${ }^{1}$, Carlos E. Rezende ${ }^{1}$, Ricardo A. Azevedo ${ }^{2}$ and Jurandi G. Oliveira ${ }^{3}$
}

\footnotetext{
${ }^{1}$ Laboratório de Ciências Ambientais, Centro de Biociência e Biotecnologia, Universidade Estadual do Norte Fluminense, 28013-602 Campos dos Goytacazes, RJ, Brasil

${ }^{2}$ Departamento de Genética, Escola Superior de Agricultura Luiz de Queiroz, Universidade de São Paulo, 13400 970 Piracicaba, SP, Brasil

${ }^{3}$ Laboratório de Melhoramento Genético Vegetal, Centro de Ciências e Tecnologias Agropecuárias, Universidade Estadual do Norte Fluminense, 28013-602 Campos dos Goytacazes, RJ, Brasil
}

* Corresponding author: apvitoria@gmail.com. FAX: (+55) 22 2739-7138

Received: 05 March 2010; Accepted: 09 April 2010.

\begin{abstract}
The ecophysiological adaptations of water hyacinth (metal hyperaccumulator) under adverse environmental conditions are not yet clearly elucidated. This work evaluated photosynthetic pigments and chlorophyll a fluorescence in water hyacinth plants sampled in different regions (upper, middle and lower) of Paraíba do Sul river (PSR) and Imbé river, Brazil. Additionally Mn, Fe, Zn, Cu, Cr, Pb and Ni were quantified on the shoots and roots. Roots were the preferential site of metal accumulation. Cromium was not detected in the shoots. Iron and Mn were the elements detected in higher concentrations in all samples. Zinc and Cu were detected in higher concentrations in roots of plants from middle and upper PSR, sites of higher anthropogenic activity. The highest concentrations of almost all metals were verified in plants from middle PSR. Regarding photosynthetic adaptations, plants from middle and upper PSR showed the highest concentrations of photosynthetic pigments, as well as the highest values of $F_{v} / F_{m}$ and $F_{v} / F_{0}$. The photosynthetic performance of plants suggests that they are not under stress conditions, even in regions of higher anthropogenic activity. Positive correlation was observed among nonphotochemical quenching and carotenoids, suggesting dissipation of energy in the form of heat as an strategy to keep the stable photochemical photosynthesis functioning, confirmed by values of the $F_{v} / F_{m}$. It is possible that such adaptative strategy is efficient as a long term response to stress factors, once literature data suggest that this is not a preferential path for photosynthesis in stress circumstances under short time controlled conditions.
\end{abstract}

Key-words: pollution, Paraíba do Sul river, energy dissipation, photosynthetic pigments, nonphotochemical quenchings.

\section{RESUMO}

As adaptações ecofisiológicas de aguapé (hiperacumuladora de metais) sob condições ambientais adversas ainda não estão totalmente elucidadas. Este trabalho avaliou pigmentos fotossintéticos e fluorescência da clorofila a em aguapé coletados em diferentes regiões (alto, médio e baixo) do rio Paraíba do Sul (RPS) e no rio Imbé, Brasil. Adicionalmente $\mathrm{Mn}, \mathrm{Fe}, \mathrm{Zn}, \mathrm{Cu}, \mathrm{Pb}$ e $\mathrm{Ni}$ foram quantificados na parte área e raízes. Ferro e Mn foram os elementos detectados em maiores concentrações em todas as amostras. Zinco e Cu foram detectados em maiores concentrações nas raízes de plantas do médio e alto RPS, locais de grande atividade antropogênica. As mais elevadas concentrações de quase todos os metais foram verificadas nas plantas do 
médio RPS. Com relação às adaptações fotossintéticas, plantas do médio e alto RPS mostraram as maiores concentrações de pigmentos fotossintéticos, assim como os mais elevados valores de $F_{v} / F_{m}$ e $F_{v} / F_{0}$. As avaliações fotossintéticas destas plantas sugerem que elas não estejam sob condições de estresse, mesmo nas regiões de grande atividade antropogênica. Correlação positiva foi observada entre quenching não-fotoquímico e carotenóides, sugerindo que a dissipação de energia na forma de calor seja uma estratégia para manter o funcionamento fotossintético fotoquímico estável, confirmado pelos valores de $F_{\mathrm{v}} / F_{\mathrm{m}}$. $E$ possível que esta estratégia adaptativa seja eficiente como resposta de longo prazo, uma vez que na literatura esta não parece ser a via preferencial de adaptação a estresses de curto prazo, avaliados sob condições controladas.

Palavras-chave: poluição, rio Paraíba do Sul, dissipação de energia, pigmentos fotossintéticos, quenching não-fotoquímico.

\section{INTRODUCTION}

Water environments have become sinks of pollutant emissions containing metals. Metals are elements found in nature; however, due to growing global industrialization, the concentrations of these elements have increased, commonly having toxic effects on plants (Ferreira et al., 2002; Gratão et al., 2005) and ecosystems (Skinner et al., 2007).

Some aquatic plants accumulate metals and many species suffer phytotoxicity (Fritioff and Greger, 2006; Dhir et al., 2008; Li et al., 2008) while others easily grow in the presence of metals. An example is the hyperaccumulator Eichhornia crassipes (Mart.) Solms (water hyacinth), Pontederiaceae native to South America and widely distributed throughout the world (Odjegba and Fasidi, 2007). Depending on the river and the pollution source to the collecting point, $\mathrm{Al}, \mathrm{Cu}, \mathrm{Fe}, \mathrm{Mn}, \mathrm{Ni}, \mathrm{Cd}, \mathrm{Cr}, \mathrm{Co}, \mathrm{Pb}, \mathrm{Zn}$ and $\mathrm{Hg}$ have previously been detected in water hyacinth plants (Vesk and Allaway, 1997; Klumpp et al., 2002; Soltan and Rashed, 2003; Mangabeira et al., 2004; Skinner et al., 2007).

The presence of unusual metal ions within a plant cell can cause dramatic effects on metabolism, as inthe photosynthesis. This may occur due to different reasons: interference in photosynthetic processes promoting substitution of $\mathrm{Mg}$ in the chlorophyll molecules by other divalent ions (Kupper et al., 1998), increase of stomatal resistance to $\mathrm{CO}_{2}$ admission (Paiva et al., 2009), interference in the activity of the Calvin's cycle enzymes (Prasad, 1995), as well as in the water splitting and ion flow from PS II (Tukendorf, 1993; Prasad, 1995), among others. Due to the effect of this kind of stress on the electron transport chain, Vassilev (2002) suggests to analyze chlorophyll a fluorescence as a powerful tool to detect aquatic plants stress.

Among chlorophyll a fluorescence parameters, $F_{v} / F_{m}$ rate has been the most widely used to meter different type of stresses (Bolhar-Nordenkampf et al., 1989; Oliveira et al., 2002; Sarijeva et al., 2007; Dhir et al. 2008; Lage-Pinto et al., 2008; Paiva et al., 2009). Fluorescence quenchings are also informative tools and the association of the nonphotochemical quenchings data with carotenoids may increase and help to evaluate the plant's life quality. In this matter, energy dissipation in the form of heat as a mechanism to minimize stressing conditions in the photosynthetic process has been previously described (Demmig-Adams et al., 1989). This strategy was observed in different species under stress conditions, but little information about these mechanisms are available for water hyacinth plants.

Despite literature on water hyacinth being generous, the majority of studies focus on its hyperaccumulative capacity and use in bioremediation (Vesk et al., 1999; Lu et al., 2004; Mohanty et al., 2006; Odjegba and Fasidi, 2007). Few publications focus on ecophysiological adaptations of the species to metal pollution. Still, most part of the experiments are performed under controlled experimental conditions (Mazen and Maghraby, 1998; Soltan and Rashed 2003; Xia and Ma, 2006; Paiva et al., 2009; Oliveira et al., 2009a), resulting generally in evaluations of short time responses. Although these studies are fundamental to help understanding metal role over this species physiology, the responses obtained under natural conditions would not be necessary identical to responses under controlled conditions. This occurs due to the synergistic effect among other unfavorable factors present under natural conditions, besides the exposition time to the 
stressing conditions being longer when evaluating plants in natural habitat, allowing the observation of long time adaptative responses.

Therefore, this work had the objective to evaluate the adaptative ecophysiological strategies of the photosynthetic apparatus in water hyacinth under natural pollution conditions along two rivers in Southeast Brazilian region that differ in anthropogenic interferences. For this purpose various metals ( $\mathrm{Mn}, \mathrm{Fe}, \mathrm{Zn}, \mathrm{Cu}, \mathrm{Cr}, \mathrm{Pb}$ and $\mathrm{Ni}$ ) were quantified in roots and shoots of water hyacinth and the photosynthetic performance was verified by chlorophyll a fluorescence and photosynthetic pigments content.

\section{MATERIAL AND METHODS}

Collection points: Eichhornia crassipes (Mart.) Solms (water hyacinth) was sampled at 4 collection points (Figure 1) along $800 \mathrm{~km}$ of the upper PSR (23011 '22.9"S, 45055 '49.5" W), middle PSR (22 $28^{\prime} 93.7^{\prime \prime}$ S, $\left.44^{\circ} 04^{\prime} 70.2^{\prime \prime} \mathrm{W}\right)$ and lower PSR (21045'28.8”S, 41019'34.8”W), and the Imbé river (IR

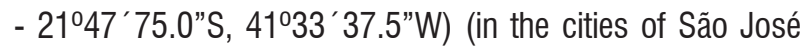
dos Campos - upper PSR, Volta Redonda - middle PSR and Campos dos Goytacazes - lower PSR and IR). Samples were obtained at the end of the rainy season of 2006 (March). Approximately 20 plants were collected at each point, at locations always close to the river bank.

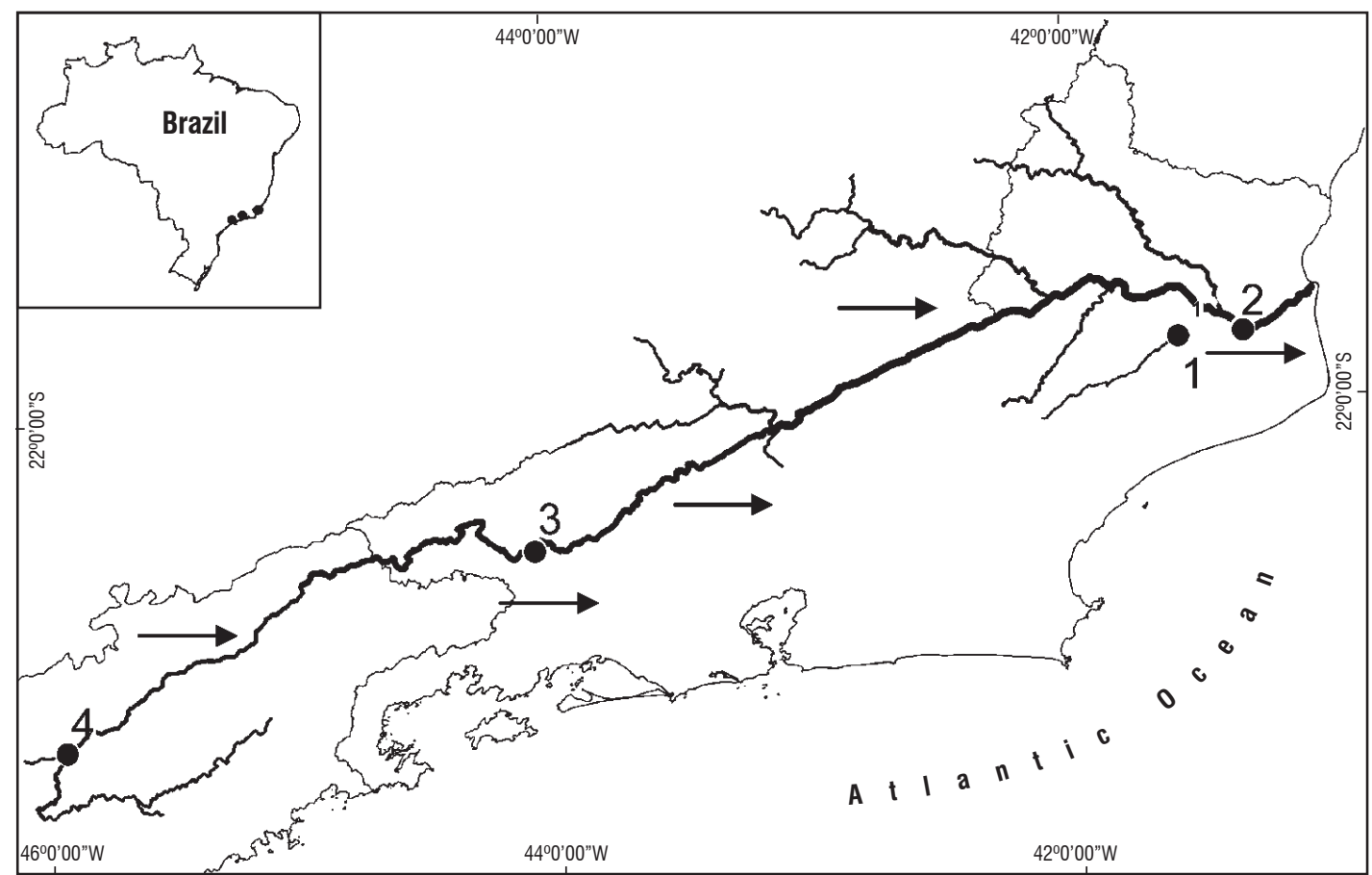

Figure 1. Water hyacinth collection points. 1 - Imbé river, 2 - lower PSR, 3 - middle PSR, 4 - upper PSR. Arrows show the direction of the water flow in the PSR. PSR - Paraíba do Sul river. Source: Lage-Pinto et al., 2008.

Metal analysis in plants: Thoroughly washed plants (three times in distilled water) were separated into the leaf limb, petiole and younger (light color and less than $10 \mathrm{~cm}$ of length) and older roots (dark color and more than $10 \mathrm{~cm}$ of length), and then frozen in liquid nitrogen. After freeze drying for 48 h (LABCONCO 260337 Freeze Dry System) and grinding of the plant parts, $500 \mathrm{mg}$ of tissue were digested following a modified version of the procedure used by Barillé-Boyer et al. (2003). The protocol consisted of an acid digestion in Teflon bombs with $10 \mathrm{~mL} \mathrm{HNO}$ (65\%) and $10 \mathrm{~mL} \mathrm{HF} \mathrm{(48 \% )} \mathrm{for} 12$ $\mathrm{h}$ at $150^{\circ} \mathrm{C}$. After digestion, the samples were resuspended in $0.5 \mathrm{M} \mathrm{HNO}_{3}$. Standard reference material was analyzed in order to estimate the recovery of the digestion method (Table 1) using Apple Leaf Reference Standard Material 1515 
supplied by the National Institute of Standards and Technology (USA). According to Table 1, the methodology was efficient to determine these metals in plants (recovery above $72 \%$ ). An atomic emission spectrometer (ICP- AES Varian Techtron) was used to detect the $\mathrm{Mn}, \mathrm{Fe}, \mathrm{Zn}, \mathrm{Cu}, \mathrm{Cr}, \mathrm{Pb}$ and Ni elements and the values were expressed in $\mathrm{mg} \mathrm{kg}^{-1}$ dry weight (DW). The samples were analyzed in triplicates and the maximum coefficient of variation obtained among the triplicates was less than $10 \%$. The detection limits are showed in Table 1.

Table 1. Detection limits to atomic emission spectrometer and recovery of metals in apple leaf reference standard material 1515 supplied by the National Institute of Standards and Technology (USA). nd - not detected.

\begin{tabular}{c|c|c|c|c|c|c|c}
\hline & $\mathbf{M n}$ & $\mathbf{F e}$ & $\mathbf{C u}$ & $\mathbf{Z n}$ & $\mathbf{~ N i}$ & $\mathbf{C r}$ & $\mathbf{P b}$ \\
\hline $\begin{array}{c}\text { \% of recovery } \\
\text { (apple leaf) }\end{array}$ & 72 & 103 & 80 & 78 & n.d. & n.d. & n.d. \\
\hline $\begin{array}{c}\text { Detection limits } \\
\text { (mg Kg-1) }\end{array}$ & 0 & 0.2 & 0.7 & 0.3 & 0.8 & 0.7 & 0.3 \\
\hline
\end{tabular}

Photosynthetic pigments content: Three discs were taken from each treatment (collecting point) and used to quantify the photosynthetic pigments content. Discs were sliced and placed in plastic tubes in the dark with a lid containing $5 \mathrm{~mL}$ dimethylsulfoxide reagent (DMSO) as organic solvent. After five days, the extract was analyzed in spectrophotometer at 480,649 and $665 \mathrm{~nm}$. The photosynthetic pigments were quantified using the equations by Wellburn (1994) for carotenoids, chlorophyll $a$ and chlorophyll $b$. The total chlorophyll, chlorophyll $a / b$ and total chlorophyll/carotenoid ratios were calculated. All the laboratory procedures were carried out in a low light environment. The values were expressed in nmol.cm².

Chlorophyll a fluorescence parameters: Chlorophyll a fluorescence parameters were determined between 9:30 a.m. and 11:00 a.m. using a portable modulated pulse fluorimeter (MINI PAM, Walz, Germany). Ten intact, totally expanded and healthy leaves from each collecting point were kept in the dark for 30 min with clamps and exposed to the weak, modulated light beam (approximately $6 \mu \mathrm{mol} \mathrm{m} \mathrm{m}^{-2} \mathrm{~s}^{-1}$ at $660 \mathrm{~nm}$ ), followed by exposure for $0.8 \mathrm{~s}$ of high intensity $\left(10000 \mu \mathrm{mol} \mathrm{m}^{-2} \mathrm{~s}^{-1}\right)$ actinic white light, adapted by Genty et al. (1989) and van Kooten and Snel (1990). The following chlorophyll a fluorescence emission parameters were recorded: $F_{0}$ (minimal fluorescence), $F_{m}$ (maximum fluorescence) and nonphotochemical quenching coefficients ( $\mathrm{qN}$ and NPQ). Other calculated fluorescence parameters included the variable fluorescence $\left(F_{v}=F_{m}-F_{0}\right)$, maximum quantum efficiency $\left(F_{v} / F_{m}\right)$ and variable chlorophyll fluorescence ratio $\left(F_{v} / F_{0}\right)$. The values are presented as the mean of ten measurements, representing ten replicates.

Statistical analysis: The results of metal concentrations, chlorophyll a fluorescence parameters and photosynthetic pigments content were submitted to analyses of variance (ANOVA), and the means were compared using Tukey's test $(p \leq 0.05)$. Pearson's correlation coefficient $(r)$ were calculated between the nonphotochemical quenching parameters (NPQ and $\mathrm{qN}$ ) and the concentrations of carotenoids pigments $(n=40)$.

\section{RESULTS}

Metal analysis in plants: According to Table 2, the roots (young and old) were the main sites of metal accumulation when compared to the shoots (petioles and leaf limb) for all metals. Manganese and Fe were the metals detected in highest concentrations for all tissues. Only $\mathrm{Cr}$ was not detected in shoots, and in addition to $\mathrm{Pb}$ and $\mathrm{Ni}$ these were the metals found in the lowest concentration. Roots of plants from middle PSR had the higher concentrations of $\mathrm{Cr}, \mathrm{Pb}$ and $\mathrm{Ni}$ (24.0, 9.01 and $10.6 \mathrm{mg} \mathrm{Kg}^{-1} \mathrm{DW}$, respectively). In most cases ( $\mathrm{Fe}, \mathrm{Cu}, \mathrm{Cr}, \mathrm{Pb}$ and $\mathrm{Ni}$ ), the samples taken in the middle PSR contained the higher metals concentrations than another collecting points, although in some cases statistical difference was not observed between samples from middle and upper PSR (Table 2).

Table 2. Metal concentrations ( $\mathrm{mg} \mathrm{kg}^{-1} \mathrm{dry}$ weight) in water hyacinth parts from four collections point (rio Imbé, lower, middle and upper PSR) in March 2006. Upper case letters - different collection point. Lower case letters - different parts of the plant in same collection point. Different letters are significantly different $(p \leq 0.05)$. PSR - Paraíba do Sul River.

\begin{tabular}{|c|c|c|c|c|c|}
\hline & & Imbé River & lower PRS & middle PSR & upper PSR \\
\hline \multirow{4}{*}{$\stackrel{c}{\Sigma}$} & leaf limb & $1025 \pm 12.5 \mathrm{Ac}$ & $471 \pm 9.46 \mathrm{Cb}$ & $433 \pm 0.00 \mathrm{Dd}$ & $556 \pm 4.47 \mathrm{Bd}$ \\
\hline & petiole & $1520 \pm 58.4 \mathrm{Ab}$ & $518 \pm 8.69 \mathrm{Db}$ & $659 \pm 5.00 \mathrm{Cc}$ & $864 \pm 17.3 \mathrm{Bc}$ \\
\hline & younger root & $1560 \pm 18.9 \mathrm{Bb}$ & $637 \pm 31.0 \mathrm{Cb}$ & $1968 \pm 47.3 \mathrm{Aa}$ & $2063 \pm 0.00 \mathrm{Ab}$ \\
\hline & older root & $3558 \pm 0.00 \mathrm{Ba}$ & $2773 \pm 67.6 \mathrm{Ca}$ & $1039 \pm 52.7 \mathrm{Db}$ & $4883 \pm 94.6 \mathrm{Aa}$ \\
\hline
\end{tabular}


Continuation Table $2 \ldots$

\begin{tabular}{|c|c|c|c|c|c|}
\hline & & Imbé River & lower PRS & middle PSR & upper PSR \\
\hline \multirow{4}{*}{ Ф } & leaf limb & $56 \pm 11.18 \mathrm{Dc}$ & $218 \pm 12.91 \mathrm{Bc}$ & $347 \pm 33.54 \mathrm{Ab}$ & $31 \pm 6.16 \mathrm{Cb}$ \\
\hline & petiole & $10 \pm 5.11 \mathrm{Dc}$ & $102 \pm 11.90 \mathrm{Bc}$ & $285 \pm 6.13 \mathrm{Ab}$ & $95 \pm 12.26 \mathrm{Bb}$ \\
\hline & younger root & $3706 \pm 0.00 \mathrm{Cb}$ & $5774 \pm 321.79 \mathrm{Bb}$ & $14685 \pm 198.05 \mathrm{Aa}$ & $173 \pm 0.00 \mathrm{Db}$ \\
\hline & older root & $8815 \pm 0.00 \mathrm{Ba}$ & $6913 \pm 148.60$ Вса & $13656 \pm 396.11 \mathrm{Aa}$ & $5044 \pm 851.39 \mathrm{Ca}$ \\
\hline \multirow{4}{*}{ 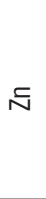 } & leaf limb & $27 \pm 0.80 \mathrm{Cc}$ & $36 \pm 0.93 \mathrm{Bd}$ & $58 \pm 0.81 \mathrm{Ac}$ & $52 \pm 0.38 \mathrm{Ad}$ \\
\hline & petiole & $25 \pm 0.70 \mathrm{Cc}$ & $30 \pm 0.55 \mathrm{Cc}$ & $59 \pm 1.96 \mathrm{Bc}$ & $92 \pm 0.00 \mathrm{Ac}$ \\
\hline & younger root & $56 \pm 0.93 \mathrm{Cb}$ & $64 \pm 1.87 \mathrm{Cb}$ & $138 \pm 3.29 \mathrm{Ba}$ & $166 \pm 1.64 \mathrm{Ab}$ \\
\hline & older root & $67 \pm 0.93 \mathrm{Da}$ & $78 \pm 0.51 \mathrm{Ca}$ & $113 \pm 1.64 \mathrm{Bb}$ & $228 \pm 2.85 \mathrm{Aa}$ \\
\hline \multirow{4}{*}{ ઉ } & leaf limb & $7.92 \pm 0.51 \mathrm{Bc}$ & $14.6 \pm 2.35 \mathrm{Aa}$ & $13.0 \pm 0.00 \mathrm{Ac}$ & $14.3 \pm 1.29 \mathrm{Ab}$ \\
\hline & petiole & $6.83 \pm 0.17 \mathrm{Cc}$ & $7.83 \pm 1.08 \mathrm{Cb}$ & $11.1 \pm 0.55 \mathrm{Ac}$ & $10.6 \pm 0.55 \mathrm{Ac}$ \\
\hline & younger root & $9.97 \pm 0.00 \mathrm{Cb}$ & $15.1 \pm 0.51 \mathrm{Ba}$ & $20.2 \pm 0.51 \mathrm{Aa}$ & $22.3 \pm 0.00 \mathrm{Aa}$ \\
\hline & older root & $14.0 \pm 0.51 \mathrm{Aa}$ & $13.9 \pm 0.45 \mathrm{Aa}$ & $16.6 \pm 0.51 \mathrm{Ab}$ & $16.6 \pm 0.51 \mathrm{Ab}$ \\
\hline \multirow{4}{*}{ ঠ } & leaf limb & $<0.7$ & $<0.7$ & $<0.7$ & $<0.7$ \\
\hline & petiole & $<0.7$ & $<0.7$ & $<0.7$ & $<0.7$ \\
\hline & younger root & $4.00 \pm 0.28 \mathrm{Cb}$ & $9.00 \pm 0.64 \mathrm{Ba}$ & $24.0 \pm 1.16 \mathrm{Aa}$ & $4.00 \pm 0.26 \mathrm{Cb}$ \\
\hline & older root & $10.0 \pm 0.48 \mathrm{Ba}$ & $9.00 \pm 0.40 \mathrm{Ba}$ & $17.0 \pm 1.12 \mathrm{Ab}$ & $7.00 \pm 0.80 \mathrm{Ba}$ \\
\hline \multirow{4}{*}{2} & leaf limb & $0.84 \pm 0.68 \mathrm{a}$ & $<0.3$ & $<0.3$ & $<0.3$ \\
\hline & petiole & $3.60 \pm 2.49 \mathrm{Aa}$ & $2.14 \pm 2.01 \mathrm{Aa}$ & $1.46 \pm 0.98 \mathrm{Ab}$ & $<0.3$ \\
\hline & younger root & $0.98 \pm 0.20 \mathrm{Ba}$ & $1.43 \pm 0.37 \mathrm{Ba}$ & $9.01 \pm 0.69 \mathrm{Aa}$ & $2.43 \pm 0.28 \mathrm{Bb}$ \\
\hline & older root & $4.03 \pm 0.96 \mathrm{BCa}$ & $1.69 \pm 0.66 \mathrm{Ca}$ & $7.60 \pm 0.54 \mathrm{Aa}$ & $5.63 \pm 0.57 \mathrm{ABa}$ \\
\hline \multirow{4}{*}{$\bar{z}$} & leaf limb & $<0.8$ & $<0.8$ & $<0.8$ & $<0.8$ \\
\hline & petiole & $<0.8$ & $2.71 \pm 0.74 \mathrm{Aab}$ & $3.28 \pm 0.53$ Aab & $2.38 \pm 1.99 \mathrm{Aa}$ \\
\hline & younger root & $1.77 \pm 0.42 \mathrm{Ba}$ & $6.62 \pm 0.86 \mathrm{ABa}$ & $10.6 \pm 2.31 \mathrm{Aa}$ & $3.94 \pm 0.06 \mathrm{Ba}$ \\
\hline & older root & $2.11 \pm 0.63 \mathrm{Aa}$ & $4.14 \pm 1.55 \mathrm{Aab}$ & $6.23 \pm 2.54 \mathrm{Aab}$ & $4.69 \pm 0.34 \mathrm{Aa}$ \\
\hline
\end{tabular}

Photosynthetic pigments: The photosynthetic pigments (chlorophyll $a, b$ and carotenoids) were the highest in plants from the middle and upper PSR (Table 3). Chlorophyll a was approximately at least $50 \%$ higher in these plants, with an average increase of chlorophyll $b$ and carotenoids being at least $25 \%$ and $40 \%$, respectively. However, the ratio chlorophyll $a / b$ had a little variation between the collecting points (3.1 - 3.5 to IR and middle PSR, respectively) and the ratio total chlorophyll/carotenoid was not significantly different (Table 3).

Table 3. Photosynthetic pigments $\left(\mathrm{nmol} . \mathrm{cm}^{-2}\right.$ ) and nonphotochemical quenchings in water hyacinth from Imbé river, lower, middle and upper PSR. Different letters are significantly different $(p \leq 0.05)$. PSR - Paraíba do Sul River. Chl - chlorophyll. Caro - cartenoids.

\begin{tabular}{ccccc}
\hline Parameters & Imbé river & lower PRS & middle PRS & upper PRS \\
\hline Chl a & $25.0 \pm 2.0 \mathrm{~b}$ & $20.7 \pm 1.8 \mathrm{~b}$ & $34.3 \pm 2.2 \mathrm{a}$ & $37.9 \pm 2.7 \mathrm{a}$ \\
$\mathrm{Chl} \mathrm{b}$ & $7.9 \pm 0.7 \mathrm{bc}$ & $6.6 \pm 0.7 \mathrm{c}$ & $9.8 \pm 0.7 \mathrm{ab}$ & $11.2 \pm 0.7 \mathrm{a}$ \\
$\mathrm{Chl} \mathrm{a/b}$ & $3.1 \pm 0.06 \mathrm{~b}$ & $3.2 \pm 0.08 \mathrm{~b}$ & $3.5 \pm 0.05 \mathrm{a}$ & $3.3 \pm 0.09 \mathrm{ab}$ \\
total Chl & $33.0 \pm 2.7 \mathrm{~b}$ & $27.3 \pm 2.4 \mathrm{~b}$ & $44.0 \pm 2.7 \mathrm{a}$ & $49.1 \pm 3.4 \mathrm{a}$ \\
Caro & $9.5 \pm 0.6 \mathrm{~b}$ & $7.4 \pm 0.5 \mathrm{~b}$ & $13.4 \pm 1.0 \mathrm{a}$ & $13.6 \pm 0.8 \mathrm{a}$ \\
total Chl/Caro & $3.4 \pm 0.1 \mathrm{a}$ & $3.7 \pm 0.1 \mathrm{a}$ & $3.3 \pm 0.2 \mathrm{a}$ & $3.6 \pm 0.1 \mathrm{a}$ \\
NPQ & $0.29 \pm 0.01 \mathrm{~b}$ & $0.32 \pm 0.04 \mathrm{ab}$ & $0.40 \pm 0.02 \mathrm{a}$ & $0.33 \pm 0.01 \mathrm{ab}$ \\
GN & $0.22 \pm 0.01 \mathrm{~b}$ & $0.20 \pm 0.02 \mathrm{~b}$ & $0.28 \pm 0.02 \mathrm{a}$ & $0.21 \pm 0.01 \mathrm{~b}$ \\
\hline
\end{tabular}


Chlorophyll a fluorescence parameters: The chlorophyll a fluorescence ratios emphasizes the similarities of responses between plants from middle and upper PSR and between plants from lower PSR and IR (Figure 2). The ratio $F_{v} / F_{m}$ ranged from

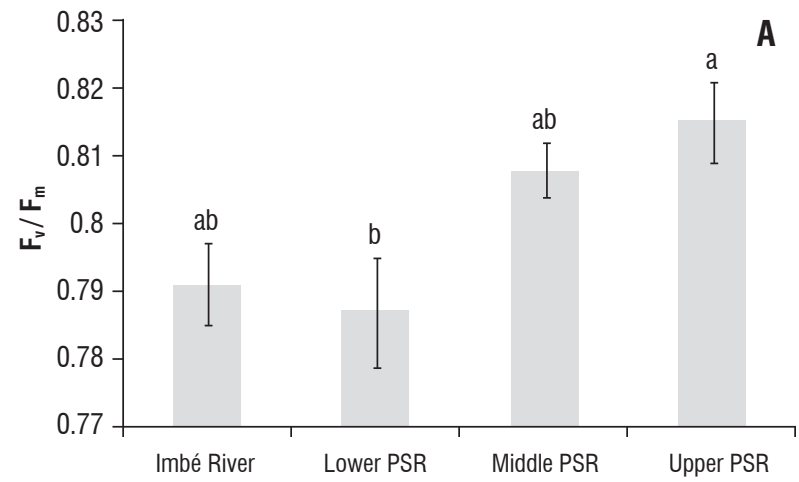

0.788 to 0.814 (lower and upper PSR, respectively) and the ratio $F_{v} / F_{0}$ was the most effective to discriminate the collecting points, with higher values also for plants from the middle and upper PSR.

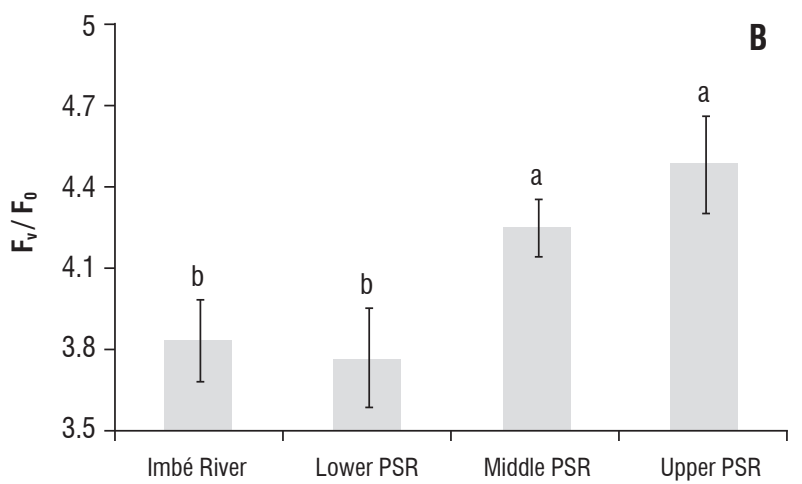

Figure 2. Chlorophyll a fluorescence ratios $\left(A-F_{v} / F_{m}\right.$ and $\left.B-F_{v} / F_{0}\right)$ in water hyacinth leaves adapted to the dark from four collecting points: Imbé river (IR), lower, middle and upper PSR in March 2006. Values represent the mean of ten measurements. Error bars represent standard errors. Means with the same letter are not significantly different $(p<0.05)$.

Values of $\mathrm{qN}$ in plants sampled in the middle PSR were greater than in the other environments $(p \leq 0.05)$ (Table 3). Although absolute values showed that NPQ was higher in plants from the middle PSR, there was no statistical difference between in NPQ from PSR plants. Still, plants from the Imbé River had lower NPQ than the rest. Pearson's correlation between nonphotochemical quenching and carotenoids concentrations showed a significant correlation for both parameters. Correlation between qN and carotenoids had $r$ : 0.4073 and $p: 0.0091$, while correlation between $\mathrm{NPQ}$ and carotenoids had $r: 0.4390$ and $p: 0.0046$ (Figure 3).

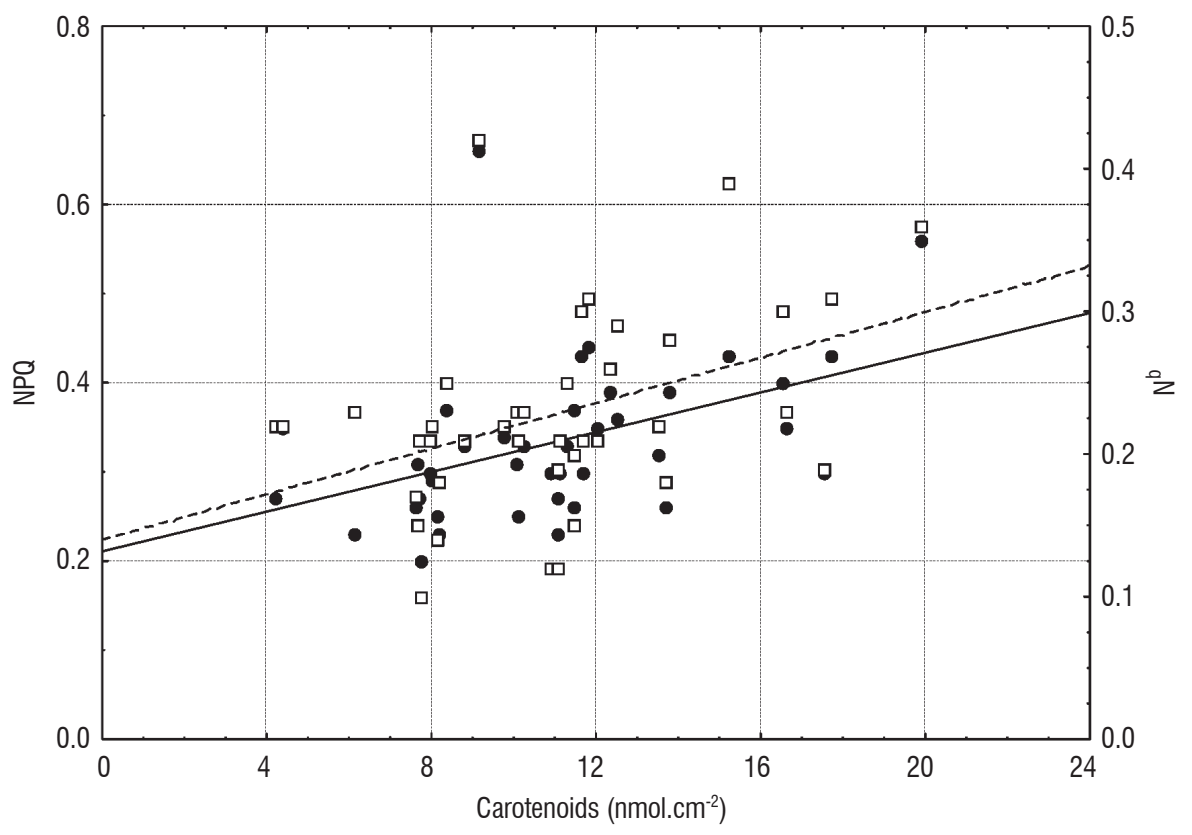

Figure 3. Pearson's correlation between nonphotochemical quenchings ( $\mathrm{qN}$ and $\mathrm{NPQ}$ ) and carotenoids. $\bullet \mathrm{NPQ}$ and $\square \mathrm{qN}$. 


\section{DISCUSSION}

Iron and $\mathrm{Mn}$ were the elements detected in the highest concentrations (Table 2), predominantly in roots. According to Ajmal et al. (1987), Fe was the most abundant in water, sediments, fish and water hyacinth and Mn was the second most abundant element in this specie from the Hindon River, India (Table 4). However, Fe and Mn values detected in our study are much higher than those reported by Ajmal et al. (1987). Higher concentrations of Fe detected in plants from PSR are probably due to the natural characteristics of this basin (Carvalho et al., 1999).

Table 4. Metal concentration (mg kg-1 dry weight) in water hyacinth from some river/water bodies of the world. $\mathrm{r}$ - root and s-shoot. * values to complete plant. Approximate values. - not detected or investigated.

\begin{tabular}{|c|c|c|c|c|c|c|c|c|}
\hline \multirow{2}{*}{$\begin{array}{c}\text { River/water } \\
\text { bodies, country }\end{array}$} & \multicolumn{7}{|c|}{ Variations of metal concentration ( $\mathrm{mg} \mathrm{kg}^{-1} \mathrm{dry}$ weight) in water hyacinth } & \multirow{2}{*}{ Reference } \\
\hline & $\mathrm{Zn}$ & $\mathrm{Fe}$ & $\mathrm{Mn}$ & $\mathrm{Cu}$ & $\mathrm{Cr}$ & $\mathrm{Pb}$ & $\mathrm{Ni}$ & \\
\hline Hindon, India & 15 to 120 & 1462 to 8437 & 156 to 689 & 3.90 to 18.3 & 1.5 to 15.75 & 3.00 to 11.25 & 8.32 to 18.45 & $\begin{array}{l}\text { Ajmal et al. } \\
(1987)^{\star}\end{array}$ \\
\hline $\begin{array}{l}\text { Wetland } \\
\text { in Sidney, } \\
\text { Australia }\end{array}$ & - & - & - & 14.7 to $303 \mathrm{r}$ & - & 145 to $1110 r$ & - & $\begin{array}{c}\text { Vesk and } \\
\text { Allaway (1997) }\end{array}$ \\
\hline $\begin{array}{l}\text { Cachoeira, } \\
\text { Brazil }\end{array}$ & & & & $\begin{array}{c}9.18 \text { to } 21.1 \mathrm{r} \\
4.9 \text { to } 7 \mathrm{~s}\end{array}$ & $\begin{array}{l}3.71 \text { to } 12.5 \mathrm{r} \\
0.7 \text { to } 1.14 \mathrm{~s}\end{array}$ & - & - & $\begin{array}{l}\text { Klumpp et al., } \\
2002\end{array}$ \\
\hline Nile, Egypt & $\begin{array}{l}295 \pm 10 r \\
11 \pm 14 s\end{array}$ & - & $\begin{array}{c}1485 \pm 110 r \\
615 \pm 65 s\end{array}$ & $\begin{array}{c}142 \pm 19 r \\
43 \pm 7 s\end{array}$ & $\begin{array}{c}100 \pm 9 r \\
41 \pm 6.5 \mathrm{~s}\end{array}$ & $\begin{array}{l}185 \pm 13 r \\
41 \pm 8.5 s\end{array}$ & $\begin{array}{l}97 \pm 13 r \\
33 \pm 7 s\end{array}$ & $\begin{array}{c}\text { Soltan and } \\
\text { Rashed (2003) }\end{array}$ \\
\hline $\begin{array}{l}\text { Ditch in } \\
\text { Bangkok, } \\
\text { Thailand }\end{array}$ & $\begin{array}{l}\sim 500 \mathrm{r} \\
\sim 400 \mathrm{~s}\end{array}$ & - & - & - & - & - & - & Lu et al. (2004) \\
\hline $\begin{array}{l}\text { Cachoeira, } \\
\text { Brasil }\end{array}$ & - & - & - & - & 70 & - & - & $\begin{array}{l}\text { Mangabeira et } \\
\text { al. (2004) * }\end{array}$ \\
\hline $\begin{array}{l}\text { Lake Yezhihu, } \\
\text { China }\end{array}$ & - & - & - & 11 to 18.1 & - & - & - & $\begin{array}{l}\text { Hu et al. } \\
(2007)^{\star}\end{array}$ \\
\hline $\begin{array}{l}\text { Almendares, } \\
\text { Cuba }\end{array}$ & 35 to $392 r$ & - & - & 11 to $74 r$ & 18 to $281 \mathrm{r}$ & 12 to $144 \mathrm{r}$ & $<1.9$ to $62 \mathrm{r}$ & $\begin{array}{l}\text { Olivares- } \\
\text { Reiumount et al. } \\
(2007)\end{array}$ \\
\hline $\begin{array}{c}\text { Paraíba do Sul, } \\
\text { Brazil }\end{array}$ & $\begin{array}{l}64 \text { to } 228 \mathrm{r} \\
30 \text { to } 92 \mathrm{~s}\end{array}$ & $\begin{array}{c}173 \text { to } 14685 \mathrm{r} \\
31 \text { to } 347 \mathrm{~s}\end{array}$ & $\begin{array}{l}637 \text { to } 4883 r \\
433 \text { to } 864 \text { s }\end{array}$ & $\begin{array}{l}13.9 \text { to } 22.3 \mathrm{r} \\
7.83 \text { to } 14.6 \mathrm{~s}\end{array}$ & $\begin{array}{l}4 \text { to } 24 \mathrm{r} \\
<0.7 \mathrm{~s}\end{array}$ & $\begin{array}{l}1.43 \text { to } 9.01 \mathrm{r} \\
<0.3 \text { to } 2.14 \mathrm{~s}\end{array}$ & $\begin{array}{l}3.94 \text { to } 10.6 r \\
0.28 \text { to } 3.28 \mathrm{~s}\end{array}$ & This study \\
\hline Imbé, Brazil & $\begin{array}{l}56 \text { to } 67 r \\
25 \text { to } 27 \mathrm{~s}\end{array}$ & $\begin{array}{c}3706 \text { to } 8815 r \\
10 \text { to } 56 \mathrm{~s}\end{array}$ & $\begin{array}{l}1560 \text { to } 3558 r \\
1025 \text { to } 1520 \mathrm{~s}\end{array}$ & $\begin{array}{c}9.97 \text { to } 14 \mathrm{r} \\
6.83 \text { to } 7.92 \mathrm{~s}\end{array}$ & $\begin{array}{l}4 \text { to10 } r \\
<0.7\end{array}$ & $\begin{array}{l}0.98 \text { to } 4.03 \mathrm{r} \\
0.84 \text { to } 3.60 \mathrm{~s}\end{array}$ & $\begin{array}{l}1.77 \text { to } 2.11 \mathrm{r} \\
<0.8 \text { to } 0.21 \mathrm{~s}\end{array}$ & This study \\
\hline
\end{tabular}

Preferential accumulation of metals in plant roots, as observed in the present study, seems to be a generalized strategy to minimize damages caused by these elements in plants (Vitória et al., 2001; Pereira et al., 2002; Skrebsky et al. 2008). Other studies on water hyacinth have also shown this (Soltan and Rashed 2003; Lu et al., 2004; Mangabeira et al., 2004; Olivares-Reiumont et al., 2007; Paiva et al., 2009). The presence of metals in tissues of the aerial part in higher concentrations than usually required by the plant metabolism may inhibit growth by interfering in important physiological processes, such in photosynthesis and respiration (Yruela, 2005). However, it should be also considered that the apparent preferential sequestration of high concentration of $\mathrm{Fe}$ and $\mathrm{Mn}$ in the roots may be due to methodological limitations, like inefficient washings in distilled water to remove $\mathrm{Fe}$ and $\mathrm{Mn}$ adsorbed onto the root surface. Vesk et al. (1999) suggested this possibility and demonstrated the difficulty of successfully removing Fe from the external part of the water hyacinth, prior to acid digestion. The formation of Fe plaques on aquatic plants roots has been also reported (Povidisa et al., 2009) and this probably difficult the exactitude in quantifying this metal. When another hyperaccumulator (Arabidopsis halleri) was submitted to growth in a hydroponic solution containing $\mathrm{Cd}$ and $\mathrm{Zn}$, the cell walls of epidermal cells retained practically all these ions, suggesting that accumulation of these metals may be due to the precipitation of $\mathrm{Cd}$ and $\mathrm{Zn}$ phosphate in the cell wall of 
root cells (Cosio et al., 2004). However, when metals enter in the cell, in general they are restrained in vacuole, in a process crucial of detoxification. The sequestration of these elements into the vacuole would drastically reduce their concentration in the cytoplasm, thus preventing or avoiding the damage to the physiological and biochemical cell processes (Prasad, 1995).

In the present study $\mathrm{Cr}$ was the only metal detected only in roots. However, $\mathrm{Cr}$ was already found in shoots of water hyacinth (Klumpp et al., 2002; Soltan and Rashed, 2003; Mangabeira et al., 2004; Paiva et al., 2009). According to Table 2, the higher concentrations of $\mathrm{Cr}$ were observed in water hyacinth roots from the middle PSR, in some cases with values inferior to concentrations detected in plants from other polluted rivers (Table 4). In this study, other elements with lower concentrations than plants inhabiting other world rivers were $\mathrm{Pb}, \mathrm{Ni}, \mathrm{Cu}$, and $\mathrm{Zn}$. The tolerance of this species to several metals was analyzed under experimental conditions by Odjegba and Fasidi (2007), the authors detected that the order of tolerance was $\mathrm{Zn}>\mathrm{Cr}>\mathrm{Ag}>\mathrm{Pb}>\mathrm{Cd}>\mathrm{Cu}>\mathrm{Ni}>\mathrm{Hg}$. Thus, it is possible that the $\mathrm{Zn}$ and $\mathrm{Cr}$ concentrations of this study may not be considered detrimental to water hyacinth development. Hu et al. (2007), suggest that this species can tolerate moderate concentrations of $\mathrm{Cu}$ (with approximately $30 \mathrm{mg} \mathrm{kg}^{-1} \mathrm{DW}$ ) without significant changes in photosynthetic pigment concentrations, but high bioaccumulation of $\mathrm{Cu}$ (with approximately $100 \mathrm{mg} \mathrm{kg}^{-1} \mathrm{DW}$ ) could result in a significant loss of pigment concentration.

Together with plants from middle PSR, those from upper PSR also had higher concentrations of $\mathrm{Pb}, \mathrm{Cu}$ and $\mathrm{Zn}$, particularly in root system. The middle and upper PSR are the collection points that are under the greatest human influence. These regions contain steel, metal foundry, chemical, paper, petrochemical industries and middle and large-sized cities. These activities may be altering the natural conditions of the river due to the insertion of greater quantities of some metals in this ecosystem (Malm et al., 1988). In middle PSR, Azevedo et al. (2004) found polycyclic aromatic hydrocarbons, reinforcing the fact of rejects from industrial activities influencing this region of the river.

Despite the confirmed presence of polluting metals in water hyacinth in this study, according to fluorescence a chlorophyll data these plants are not stressed. The $F_{v} / F_{m}$ ratio, a quantitative measure of the photochemical efficiency of photosystem (PS) ॥, is often used as a stress indicator and describes the potential yield of the photochemical reactions (Bjoerkman and Demming, 1987; Oliveira et al., 2009b; Paiva et al., 2009). Values of $F_{v} / F_{m}$ between $0.75-0.85$ are historically considered as optimum in healthy plants, showing that the photosynthetic apparatus is highly efficient (BolharNordenkampf et al., 1989). However, different range values for $\mathrm{F}_{\mathrm{v}} / \mathrm{F}_{\mathrm{m}}$ ratio were observed. Adams and Demmig-Adams (1996) and Falbel et al. (1994) suggest that depending on the growth environment or the plant species, values ranging from 0.78 to 0.89 reflect also good quantum efficiency. Bjoerkman and Demmig (1987) suggest a most narrow range $(0.832 \pm$ 0.004 ) as indicative of unstressed plants. Our results varied from 0.788 to 0.814 , thus according the majority of authors this is an indication for healthy plants. The absence of necrosis, yellowing, blight or symptoms or any other morphological alteration (not shown) reinforces that suggestion.

The $F_{\mathrm{v}} / F_{0}$ rate followed the same tendency as the $F_{\mathrm{v}} / F_{\mathrm{m}}$ rate, however, the statistic test was more efficient to discriminate the efficiency of the photosynthetic apparatus from the middle and upper PSR plants when compared with plants from the lower PSR and IR. This fact confirms previous data from Paiva et al. (2009) and Pereira et al. (2000) working with plants exposed to metal (Cr and Al, respectively), Sarijeva et al. (2007) working with sun exposed and shaded leaves and Oliveira et al. (2009b) working with chilling stress. These authors suggested the use of $F_{v} / F_{0}$ ratio, rather than the $F_{v} / F_{m}$ ratio, for better discrimination of small differences in the $\mathrm{PS}_{\|}$quantum yield.

According to Roháček (2002), the $F_{v} / F_{0}$ ratio in healthy plants may range from 4 to 6 , representing changes in the ratio between photochemical quantum yield and the nonphotochemical concurrent processes in $\mathrm{PS}{ }_{\|}$. Figure 2B shows that plants from the lower PSR and IR had the lowest $\mathrm{F}_{\mathrm{v}} / \mathrm{F}_{0}$ ratios, probably due to the action of the polluting metals on the donator side of the PS $\|$, once nonphotochemical quenching (NPQ and $\mathrm{qN}$ ) was, in a general manner, lower in these plants when compared to the middle and upper PSR plants (Table 3). According Skórzynska-Polit and Baszynski (2000) metals as $\mathrm{Cd}^{2+}$ compete with ions like $\mathrm{Ca}^{2+}$ causing disturbances in vegetal development and growth, affecting the cell metabolism. Cadmium was not evaluated in this study, but the competition for $\mathrm{Ca}^{2+}$ channels may have occurred with other metals with the same valence $\left({ }^{2+}\right)$. Still according to Skórzynska-Polit and Baszynski (2000), the $F_{v} / F_{0}$ ratio reflects changes in the donating side of the $\mathrm{PS}_{\|}$, being this 
component of the photosynthetic apparatus more sensitive to metal action.

Plants from middle PSR had higher values of $\mathrm{qN}$ and $N P Q$. In these plants, as well as in plants from the upper PSR, a higher photosynthetic pigments content, including carotenoids, was observed (Table 3). The positive correlation between these quenchings and the content of carotenoids suggests energy dispersion in these plants as a provable mechanism to reduce load on the electron transport chain. The test of correlation between nonphotochemical quenchings ( $q \mathrm{~N}$ e NPQ) and the content of carotenoids suggests that other components, different than carotenoids, are implicated with energy dissipation absorbed in the form of heat. In agreement with the values of " $r$ " obtained, is possible to conclude that less than $50 \%$ of the qN and NPW variation is related with the carotenoids content while most part of these quenchings dispersion is related to other factors. These factors may be associated with the carotenoids composition and the participation of a low molecular weight protein known as PsbS (Li et al., 2000). PsbS protein is responsible for the linkage of the zeaxantine from the antenna complex, LHCIl, with the reaction center from the $\mathrm{PS}_{\|}$, making easy de-excitation of chlorophyll singlet (excited) with the emission of non-radiant energy, that is, in the form of heat (Niyogi et al., 2004).

Carotenoids composition is linked to the xantophiles cycle (conversion of violanthin to zeaxantine), responsible by heat dissipation in the process of protection of the PS ॥ (Adams and Demmig-Adams, 1996). The NPQ is associated with this conversion that consists of de-epoxidation of the epoxide groups from violaxanthin forming cyclohexenyl rings. This mechanism lowers the energy of the carotenoid S1 state to approximately the same level as the chlorophyll a S1 state and induces a potential new pathway for reversible singlesingle energy transfer from chlorophyll a to zeaxanthin.

Eullaffroy et al. (2009) also verified the thermal dissipation of excitation energy mechanism of the aquatic plant Lemna minor exposed to herbicides. However, little information is available in scientific literature about this adaptative mechanism in water hyacinth. The sparse data available are still conflicting, suggesting that this is not an obligate response or a short time response for this species under stress conditions. Paiva et al. (2009) did not observed increments in NPQ or carotenoids content in water hyacinth stressed with 1 to $10 \mathrm{mM}$ of $\mathrm{Cr}^{+3}$ and $\mathrm{Cr}^{+6}$ during a period of two and four days. These authors also verified reduction in $\mathrm{F}_{\mathrm{v}}$ $\mathrm{F}_{\mathrm{m}}$ and $\mathrm{F}_{\mathrm{v}} / \mathrm{F}_{0}$ ratios, reduction in $\mathrm{CO}_{2}$ assimilation and necroses in water hyacinth exposed to a $1 \mathrm{mM}$ of $\mathrm{Cr}^{+6}$. From the results obtained by Paiva et al. (2009), it is possible to suggest that under the conditions imposed by these authors, there was not enough time for the photosynthetic apparatus of water hyacinth, to protect from stress, or perhaps defenses that may have been activated, as for example thermal dissipation trough carotenoids, were not sufficient to prevent damages caused by the metal.

Andersson et al. (2006) working with the marine macroalgae Gracilaria domingensis exposed to different irradiance levels showed the interconversions of xanthophylls (violaxanthin, zeaxanthin, $\beta$-cryptoxanthin and one unidentified carotenoid), but not in response to sudden exposure to light. Simultaneous in vivo fluorescence and $\mathrm{O}_{2}$ evolution experiments were performed allowing a direct comparison of overall photosynthetic performance with NPQ. According to these authors, NPQ was not correlated with any xanthophyll cycle during short-term acclimation to light.

Working under experimental conditions, Vassilev (2002) observed the Elodea Canadensis submitted to $2 \mathrm{mg} / \mathrm{L}$ of $\mathrm{Cd}$ and $\mathrm{Cu}$ had an increment in $\mathrm{qN}$ after a $24 \mathrm{~h}$ period, but this was not enough to avoid a reduction in quantum yield on these plants.

Our results differ partially from those described in scientific literature, provably due to the natural conditions of the experiment, in the natural plant habitat. This may have made possible a sufficient time to activate and successfully use the protection mechanisms for the photosynthetic apparatus, that were not observed under experimental conditions discussed above.

Such results reinforcethe importance of complementation between laboratory and natural condition studies to evaluate plant responses to adverse environmental conditions. Ribeiro et al. (2004), working under field conditions with arboreal species of different successional groups suggested heat dissipation as an strategy for pioneer and secondary initial species, that is, those naturally more expossed to environmental conditions of light stress. This reinforces the idea of this dissipative mechanism as a long time adaptation.

Lage-Pinto et al. (2008) working with water hyacinth during the same period and localities of our work, observed 
that plants from the middle PSR had ultraestructural alterations in chloroplasts as non-stacking grana thylakoids disposition. According to these authors the decrease in PS ${ }_{\|}$and increase in the PS , (due to this ultrastructural alteration) can be an adaptive attempt for the maintenance of the electrons flow in water hyacinth under metal stress. They suggested that this alteration was important to maintain the normal photochemical activities, implying an adaptation in the adjustment to adverse environmental conditions in middle PSR plants.

Our data shows that under natural conditions, ultrastructural adaptative adjustments suggested by Lage-Pinto et al. (2008), as a response to polluted environments may also include thermal energy dissipation in this species. Certainly many other mechanisms of ecophysiological, biochemical and molecular defense may have involved in the capacity of this species to tolerate adverse conditions so far as to be considered a hyperaccumulator plant (Objegba and Fasidi, 2007).

The data presented herein represents an indication of the situation of some of the metals present in water hyacinth plants in the PSR and IR and of the ecophysiology of these plants. It is important to emphasize that, in this study, carried out under natural environmental conditions, was not possible to isolate the presence of one xenobiotic agent as being solely responsible for the alterations observed. However, the metal concentrations indicate the existence of points with more anthropogenic pollution along the PSR, and the ecophysiological data points to thermal dissipation as an adaptation of the photosynthetic apparatus of this hyperaccumulator species to tolerate adverse environmental conditions.

Acknowledgments: This work was funded by Fundação de Amparo à Pesquisa do Estado de São Paulo (FAPESP Grantn $\left.{ }^{\circ} .04 / 15012-5\right)$, Conselho Nacional de Desenvolvimento Científico e Tecnológico (CNPq - Brazil - Grant number 471091/2004-9), Instituto Nacional de Ciência e Tecnologia (INCT - CNPq Grant number 573.601/2008-9). The authors want to thank to Arizolli Antônio Rosa for the analysis of metals.

\section{REFERENCES}

Adams WWIII, Demming-Adams B (1996) Energy dissipation and the xanthophylls cycle in CAM plants. In: Winter K, Smith JAC (eds), Crassulaceae Acid Metabolism: Biochemistry, Ecophysiology and Evolution, pp.97-114. Springer, Verlag, Berlin.
Andersson M, Schubert H, Pedersen M, Snoeijs P (2006) Different patterns of carotenoid composition and photosynthesis acclimation in two tropical red algae. Mar. Biol. 149:653-665.

Ajmal M, Raziuddin, Klan AU (1987) Heavy metals in water, sediments, fish and plants of river Hindon, U.P., India. Hydrobiologia 148:151-157.

Azevedo DA, Gerchon E, Reis EO (2004) Monitoring of pesticides and polycyclic aromatic hydrocarbons in water from Paraíba do Sul river. Brazil. J. Braz. Chem. Soc. 15:292-299.

Barillé-Boyer AL, Barillé L, Massé H, Razet D, Héral M (2003) Correction for particulate organic matter as estimated by loss on ignition in estuarine ecosystems. Est. Coast. Shelf Sci. 58:147-153.

Björkman O, Demming B (1987) Photon yield of $\mathrm{O}_{2}$ evolution and chlorophyll fluorescence characteristics at $77 \mathrm{k}$ among vascular plants of diverse origins. Planta 170:61-66.

Bolhar-Nordenkampf HR, Long SP, Baker NR (1989) Chlorophyll fluorescence as probe of the photosynthetic competence of leaves in the field: a review of current instrument. Func. Ecol. 3:497-514.

Carvalho CEV, Ovalle ARC, Rezende CE, Molisani MM, Salomão MSMB, Lacerda LD (1999) Seasonal variation of particulate heavy metals in the Lower Paraíba do Sul river, RJ. J. Braz. Environ. Geol. 37:297-302.

Cosio C, Martinoia E, Keller C (2004) Hyperaccumulation of Cadmium and Zinc in Thlaspi caerulescens and Arabidopsis halleri at the Leaf Cellular Level. Plant Physiol. 134:716-725.

Demmig-Adams B, Adams WW (1996) The role of xanthophylls cycle carotenoids in the protection of photosynthesis. Trends Plant Sci. 1:21-26.

Demmig-Adams B, Winter K, Kruger A, Czygan FC (1989) Light response of $\mathrm{CO}_{2}$ assimilation, dissipation of excess excitation energy, and zeaxanthin content of sun and shade leaves. Plant Physiol. 90:881-886.

Dhir B, Sharmila P, Saradhi PP (2008) Photosynthetic performance of Salvinia natans exposed to chromium and zinc rich wastewater. Braz. J. Plant. Physiol. 20:61-70.

Eullaffroy P, Frankart C, Aziz A, Couderchet M, Blaise C (2009) Energy fluxes and driving forces for photosynthesis in Lemna minor exposed to herbicides. Aquat. Bot. 90:172-178.

Falbel GT, Staehelin LA, Adams WWIII (1994) Analysis of xanthophylls cycle carotenoids and chlorophyll fluorescence in light intensity-dependent chlorophyll-deficient mutants of wheat and barley. Photosyn. Res. 42:191202.

Ferreira RR, Fornazier RF, Vitória AP, Lea PJ, Azevedo RA (2002) Changes in antioxidant enzymes activities in soybean under cadmium stress. J. Plant Nutr.25:327-342.

Fritioff A, Greger M (2006) Uptake and distribution of $\mathrm{Zn}, \mathrm{Cu}, \mathrm{Cd}$, and $\mathrm{Pb}$ in an aquatic plant Potamogeton natans. Chemosphere 63:220-227.

Genty B, Briantais J-M, Baker NR (1989) The relationship between the quantum yield of photosynthetic electron transport and quenching of chlorophyll fluorescence. Biochim. Biophys. Acta 990:87-92.

Gratão PL, Polle A, Lea PJ, Azevedo RA (2005) Making the life of heavy metalstressed plants a little easier. Func. Plant Biol. 32:481-494.

Hu C, Zhang L, Hamilton D, Zhou W, Yang T, Zhu D (2007) Physiological responses induced by copper bioaccumulation in Eichhornia crassipes (Mart.). Hydrobiologia 579:211-218.

Klumpp A, Bauer K, Franz-Gerstein C, Menezes M (2002) Variation of nutrient and metal concentrations in aquatic macrophytes along the Rio Cachoeira in Bahia (Brazil). Environ. Int. 28:165-171.

Küpper H, Küpper F, Spiller M (1998) In sito identification of heavy metal substitute chlorophylls in water plants. Photosynthesis Res. 58:123-133.

Lage-Pinto F, Oliveira JG, Da Cunha M, Souza CMM, Rezende CE, Azevedo RA, Vitória AP (2008) Chlorophyll a fluorescence and ultrastructural changes in chloroplast of water hyacinth as indicators of environmental stress. Environ. Exp. Bot. 64 :307-313. 
Li M, Zhang J, Tao L, Li W (2008) Ecophysiological responses of Jussiaea rapens to cadmium exposure. Aquat. Bot. 88:347-352.

Li X-P, Bjorkman O, Shih C, Grossman AR, Rosenquist M, Jansson S, Niyogi KK (2000) A pigment-binding protein essential for regulation of photosynthetic light harvesting. Nature, 403:391-395.

Lu X, Kruatrachue M, Pokethitiyook P, Homyok K (2004) Removal of Cadmium and Zinc by water hyacinth, Eichhornia crassipes. Sci. Asia 30:93-1030.

Malm 0, Pfeiffer WC, Fiszman M, Azcue JM (1988) Transport and availability of heavy metals in the Paraíba do Sul - Gandu River system, Rio de Janeiro State, Brazil. Sci. Total Environ. 75:201-209.

Mangabeira PAO, Labejof L, Lamperti A, de Almeida A-AF, Oliveira AH, Escaig F, Severo MIG, Silva DC, Saloes M, Mielke MS, Lucena ER, Martins MC, Santana KB, Gavrilov KL, Galle P, Levi-Setti R (2004) Accumulation of chromium in root tissues of Eichhornia crassipes (Mart.) Solms in Cachoeira River-Brazil. Appl. Surf. Sci. 231-232:497-501.

Mazen AMA, Maghraby OMO (1998) Acumulation of cadimium, lead and strontium, and a role of calcium oxalate in water hyacinth tolerance. Biol. Plant. 40:411-417.

Mohanty K, Mousanjha BC, Meikap MNB (2006) Biosorption of $\mathrm{Cr}$ (VI) from aqueous solutions by Eichhornia crassipes. Chem. Eng. J. 117:71-77.

Niyogi KK, Li X-P, Rosenberg V, Jung H-S (2004) Is PsbS the site of nonphotochemical quenching in photosynthesis? J. Exp.Bot. 56:375-382.

Odjegba VJ, Fasidi OI (2007) Phytoremediation of heavy metals by Eichhornia crassipes. Environmentalist 27:349-355.

Olivares-Rieumont S, Lima S, De la Rosa D, Gram DW, Columbie I, Santana JL, Sánchez MJ (2007) Water hyacinths (Eichhornia crassipes) as indicators of heavy metal impact of a large landfill on the Almendares River near Havana, Cuba. Bull. Environ. Contam. Toxicol. 79:583-587.

Oliveira JA, Cambraia J, Sousa MS, Oliva MA (2009a) Sulphate uptake and metabolism in water hyacinth and salvinia during cadmium stress. Aquat. Bot. 91:257-261.

Oliveira JG, Alves PLCA, Magalhães AC (2002) The effect of chilling on the photosynthetic activity in coffee (Coffea arabica L.) seedlings. The protective action of chloroplastid pigments. Braz. J. Plant Physiol. 14:89-98.

Oliveira JG, Alves PLCA, Vitória AP (2009b) Alterations in chlorophyll a fluorescence, pigment concentrations and lipid peroxidation to chilling temperature in coffee seedlings. Environ. Exp. Bot. 67-71-76.

Paiva LB, Oliveira JG, Azevedo RA, Ribeiro DR, Silva MG, Vitória AP (2009) Ecophysiological responses of water hyacinth exposed to $\mathrm{Cr} 3+$ and $\mathrm{Cr} 6+$. Environ. Exp. Bot 65:403-409.

Pereira GLG, Molina SMG, Lea PL, Azevedo RA (2002) Activity of antioxidant enzymes in response to cadmium in Crotalaria juncea. Plant and Soil 239:123-132.

Pereira WE, Siqueira DL, Martínez CA, Puiatti M (2000) Gas exchange and chlorophyll fluorescence in four citrus rootstocks under aluminium stress. J. Plant Physiol. 157:513-520.
Povidisa K, Delefosse M, Holmer M (2009) The formation of iron plaques on roots and rhizomes of the seagrass Cymodocea serrulata (R. Brown) Ascherson with implications for sulphide intrusion. Aquat. Bot. 90:303-308.

Prasad MNV (1995) Cadmium toxicity and tolerance in vascular plants. Environ. Exp. Bot. 35:525-545.

Ribeiro RV, Souza GM, Manzatto AG, Machado EC, Oliveira RF (2004) Chlorophyll fluorescence of tropical tree species in a semi-deciduos forest gap. Árvore 28:21-27.

Roháček K (2002) Chorophyll fluorescence parameters: the definitions, photosynthetic meaning and mutual relationships. Photosynthetica 40:13-29.

Sarijeva G, Knapp M, Lichtenthaler HK (2007) Differences in photosynthetic activity, chlorophyll and carotenoid levels, and in cholorophyll fluorescence parameters in green sun and shade leaves of Ginkgo and Fagus. J. Plant Physiol. 164:950-955.

Skinner K, Wright N, Porter-Goff E (2007) Mercury uptake and accumulation by four species of aquatic plants. Environ. Pollut. 145:234-237.

Skórzynka-Polit E, Baszyhski T (2000) Does $\mathrm{Cd}^{2+}$ use $\mathrm{Ca}^{2+}$ Channels to penetrate into chloroplasts? - a preliminary study. Acta Physiol. Plant. 22:171-178.

Skrebsky EC, Tabaldi LA, Pereira LB, Rauber R, Maldaner J, Cargnelutti D, Gonçalves JF, Castro GY, Shetinger MRC, Nicoloso FT (2008) Effect of cadmium on growth, micronutrient concentration, and $\square$-aminolevulinic acid dehydratase and acid phosphatase activities in plants of Pfaffia glomerata. Braz. J. Plant Physiol. 20:285-294.

Soltan ME, Rashed MN (2003) Laboratory study on the survival of water hyacinth under several conditions of heavy metal concentrations. Adv. Environ. Res. 7:321-334.

Tukendorf A (1993) The response of spinach plants to excess of copper and cadmium. Photosynthetica 28:573-575.

Van Kooten 0, Snel JFH (1990) The use of chlorophyll fluorescence nomenclature in plant stress physiology. Photosynthesis Res. 25:147-150.

Vassilev A (2002) Use of chlorophyll fluorescence in phytotoxicity testing. II. Use of parameters at steady-state photosynthesis. J. Environ. Protec. Ecol. 3:907-912.

Vesk PA, Allaway WG (1997) Spatial variation of copper and lead concentrations of water hyacinth plants in a rainyland receiving urban run-off. Aquat. Bot. 59:33-44.

Vesk PA, Nockolds CE, Allaway WG (1999) Metal localization in water hyacinth root from an urban rainyland. Plant Cell Environ. 22:149-158.

Vitória AP, Lea PJ, Azevedo RA (2001) Antioxidant enzymes responses to cadmium in radish tissues. Phytochemistry 57:701-710.

Wellburn RA (1994) The spectral determination of chlorophylls $a$ and $b$, as well as total carotenoids, using various solvents with spectrophotometers of different resolution. Plant Physiol. 144:307-313.

Xia H, Ma X (2006) Phytoremediation of ethion by water hyacinth (Eichhornia crapisses) from water. Bior. Technol. 97:1050-1054.

Yruela I (2005) Copper in plants. Braz. J. Plant. Physiol. 17:145-156. 